\title{
An Analysis of Theme and Rheme of The Text in a Book of Physics for grade VII of Junior High School
}

\author{
Yuria Kasmita \\ Universitas Bengkulu \\ yuriakasmita@gmail.com \\ Iis Sujarwati \\ Universitas Bengkulu \\ iissujarwati@unib.ac.id
}

\begin{abstract}
Theme and rheme as the main attention which will be discussed in a text and the theme will be supported by the rheme. Rheme is supporting sentences which will explain the theme more detail, so the readers can get the messages deeply which will be conveyed by the writer. This study aims to analyse the theme and rheme in bilingual book, a Book of Physics for grade VII of Junior High School. The objective of this study to know the theme and rheme from source language into target language, whether the theme and the rheme has preserved or has changed. The object in this research is a book, a Book of Physics for grade VII of Junior High School. We will analyse some texts or passages in this which are written in English and indonesian. This research is quantitative research which will be analyzed the text descriptively based on their textual equivalence: thematic structure. The result showed that there were three kinds of themes namely linear progression, progression with constant theme and progression with derived theme.
\end{abstract}

Key words: Theme and rheme, source text, target text

\section{A. Introduction}

Translation is an activity to render a text from source text into target text with equivalence meaning. Where the meaning of source text can be preserved in target text. There is no deviation in the product of translation to achieve a good translation, a translator must acquire some elements of language which can support in translating. One of theme about theme and rheme. Yasmine K. and Houria B. stated that translation needs the knowledge about languages, both source language and target language. Besides the languages, the translation also need the knowledge of the cultures, both culture of source language and target language. There are three translation types. Those are technical, literary and pragmatics. Marin P. Allen, et al stated that translation is a changing of written forms from two languages. Translation is 
not only about the words but it is also about making intelligible a whole culture. While Yasmin and Houra stated that translation activities need the mastering of languages deeply, and acquring the social and culture of target language and knowing the translation method.while Nida (1997:42) in Dejica, stated that there is relationship between structure and text in relation to translating. So, when the translators acquire to the structure and the discourse, they can translate the text accurately. Dejica in his studies (2009) stated that acquiring the knowledges of theories will be extremely helpful for translator in translating a certain text or passage. By knowing it, the translator can know the structure of the languages, then they can decide whether the taxt form will be changed or will be preserved in target language. The things that may be considered in translating before deciding to preserve or to change the text is whether the text in target language is coherent or not, and whether the meaning or the message in target language is same with the original meaning in source language.

While I Gusti Agung I.A. et.al.(2019) stated that the specific thing that must be focused by the translators are the transfer of message especially about the knowledges which can be understood by the audiences. Sudirman in I gusti Agung I.A. (2019) claimed that the accuracy and clarity of the message conveyed from source language to target language is very important related to three things: lexical choice of words in target language (TL) that is related to the meaning in source language, the choice of particular words in target language change the meaning in source language. So, the translators have to have an ability to choose the appropriate words or to find the words which have equivalence meaning into target language. It also refers to the ability to choose the new words (neologism) and words that have a lot of meaning (polysemous). He also explained that in some cases of findings there is some words look similar in the form but can not be same in meaning.

Baker (2018) in I Gusti I.A (2019) stated that the different linguistics will affect the different of grammatical equivalence from one country to other country. So in the translating, the grammar form from one language to other language maybe changed. The purpose of translation is how the message from one language can be conveyed in other language without changing the meaning.

In research done by I Gusti I.A (2019) showed that every language may have different grammatical rules. So, it will be different the grammatical rule in source language and target 
language. In several cases, one language can adopt another language form directly but some others can't.

In other word, Yasmin and Houra stated that translation is replacement of a text or a passage equivalence from one language into another language. They also said there is controversy whether translator only translates or produces translation as close as the original text. Should the translator converts the meaning from source language (original language) into the usual, idiomatic ways of the target audience, language and text?. Based on Mona Baker,there are two ways in analysing clauses as a message namely thematic and information.

Theme is a main point of discussion in a clause or a text. The focus of discussion is called theme while the supporting sentences which explain more about theme is called rheme. Topic or theme which is required in the text or in the passage will make a passage or a text globally coherent. The topic will be in the each sentence and for each sentence connection of the passage (Van Dijk: 41). As Michael McCarthy in 1991, wrote that in English, whatever puts in the front of the clause can be signal that is a the framework which can be understood. Items that are in front place in this way called theme (topic).The readers can determine what will be discussed in a text from the theme and they will also know more detail about the theme by reading the rheme. Halliday and Mathiessen in Duane, L. stated that the theme is the point of the text. It means from theme we can know what actually the text tell about.

Based on Mona Baker (1994), there are two functions of the theme. First, the orientation can be connected back to the prior clause and thereby it maintains the coherence of the main idea. Second, the point which connect forward and develop the next stretches. She also stated that the idea of theme and rheme are related to the acceptability (rather than grammaticality) of a given sequence in a given context.

Mona Baker (1994) explained that sentences may consist some clauses that they will have some layers of thematic structure. Each clause have its theme-rheme structure, which may be subordinate to a larger theme-rheme structure.

Teun A.van Dijk stated that the topic lead the sentence and each sentence connect each other in a passage. While Halliday in Weijing stated that the starting point of message in a passage is called theme. And Duane Leonard redefined that the theme as 'everything up to the core verb' and 'the rheme as the verb and everything else.

There are three patterns of themes based on Danes in Dejica:2013: 
1. Linear progression: the rheme comes after theme. Then the rheme becomes the theme for the next sentence.

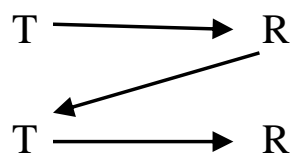

Picture 1. Linear progression

2. Progression with constant theme: the same theme will repeated for next sentence.

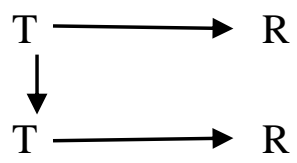

Picture 2. Progression with constant theme

3. Progression with derived theme: subsequent themes are derived from a superordinate item at the beginning of a text, in theme or rheme position

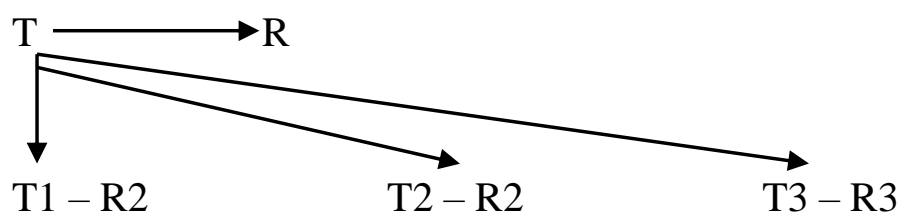

Picture 3. Progression with derived theme

In picture 1 , the rheme become the theme for the next sentence. While in picture two, the theme is repeated in the next sentence, and in picture three, the next theme derived from the first theme.

In translating, does the theme and rheme will be changed or will be preserved like the source text? As we know that in translating the main purpose is how the message can be conveyed in the same meaning from the source text. But the translation must follow the role of the source language and target language.

Daniel Dejica and Mihaela C. in their research stated that there is different pattern of textual organization between source language and target language. Besides that the source text may be different to the target text in terms of internal organization. Structure and focus. All different yet all correct, depending on the writer's intention, client's requirements or target language preferences. It also showed the fact that inadequate or inconsistent application 
of translation strategies above word level may lead to the example of incoherence at the global level of discourse.

\section{B. Research Methodology}

This research will use quantitave research to analyze the theme and rheme of The Text in a Book of Physics for grade VII of Junior High School. This research will observe whether the theme and rheme in English as the source language will be preserved or will be changed in Indonesian as the target language. The passage will be analyzed descriptively based on their textual equivalence: thematic structure. It will be analyzed related to the theme and rheme structure and their occurence and position in the sentence.

\section{Results and Discussion}

This study analyzed the theme and the rheme from Indonesian into English as TL. The study aimed to investigate whether the position of the theme and the rheme in both languages have similarities or have differences. In this study, there are two paragraph from the Book of Physics for grade VII of Junior High School.

Source Language (SL): Indonesian Text

Text 1 (paragraph 1)

Theme

Rheme

Sebelum kalian mengetahui perihal besaran dan satuan, lakukan kegiatan kecil berikut ini.

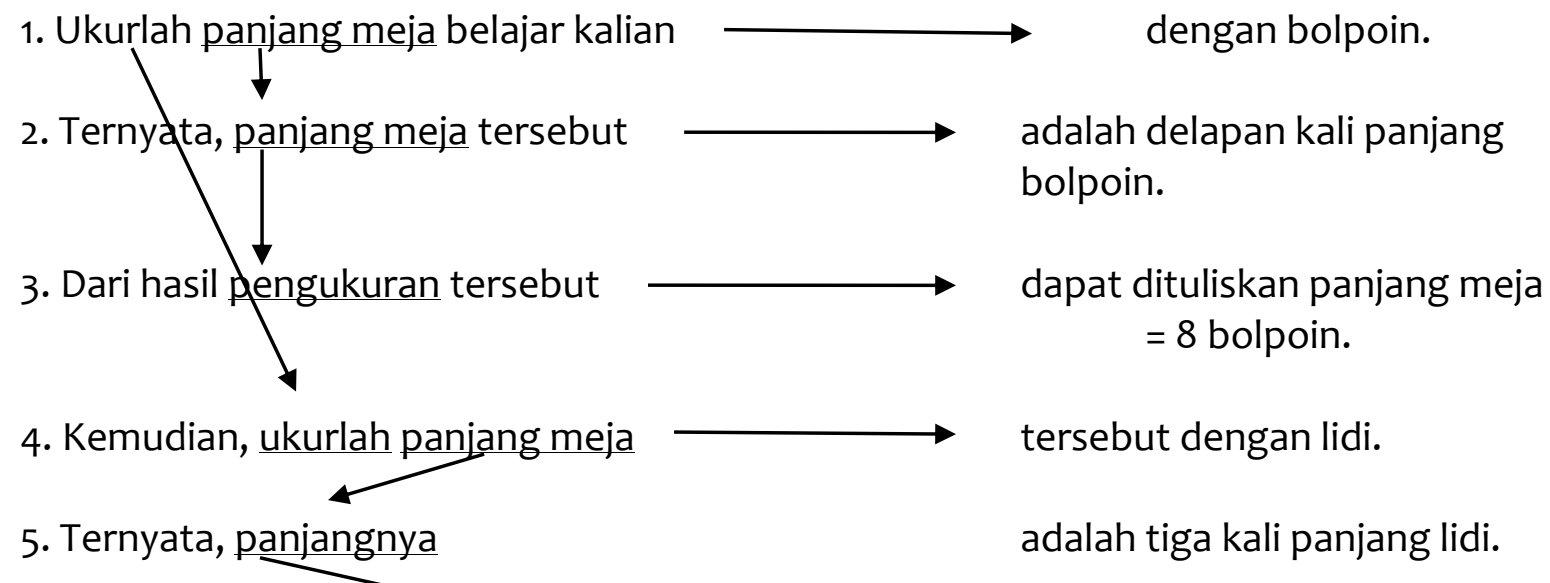


6. Jadi, hasilnya dapat ditulis panjang meja

7. Cobalah panjang meja tersebut $\longrightarrow=3$ lidi.

kalian ukur dengan alat yang lain dan tuliskan hasilnya.

(paragraph 2)

1. Dari kegiatan tersebut, mengukur

dapat diartikan sebagai kegiatan untuk membandingkan sesuatu.

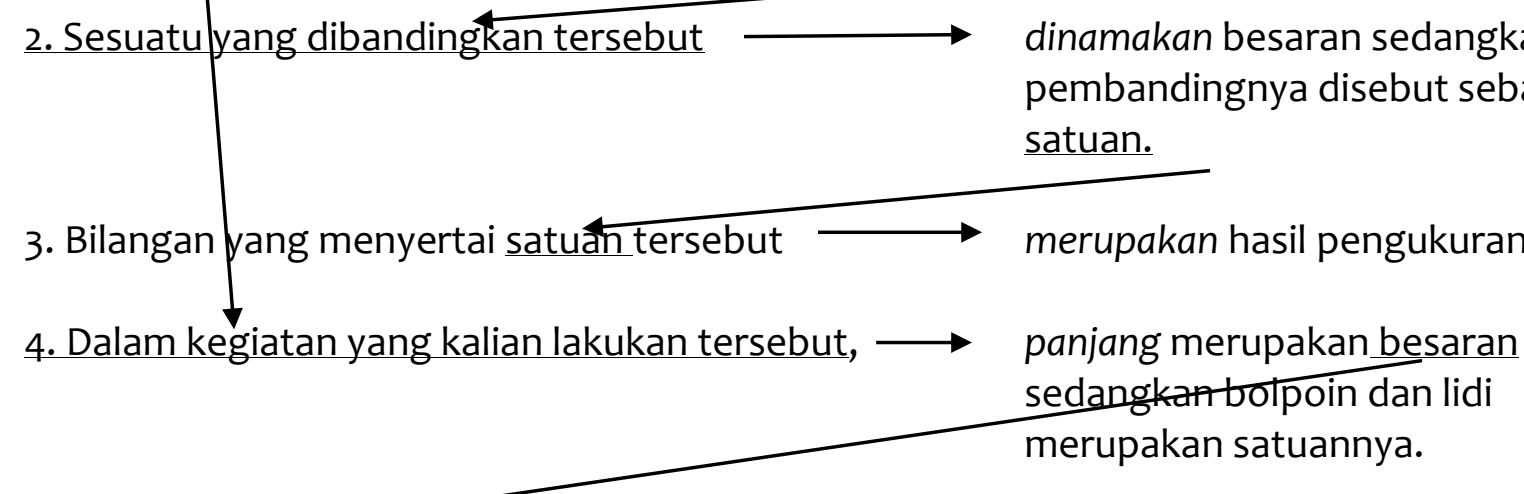

5. Jadi, besarân $\longrightarrow$ adalah sesuatu yang dapat diukur dan mempunyai satuan.

6. Satsan

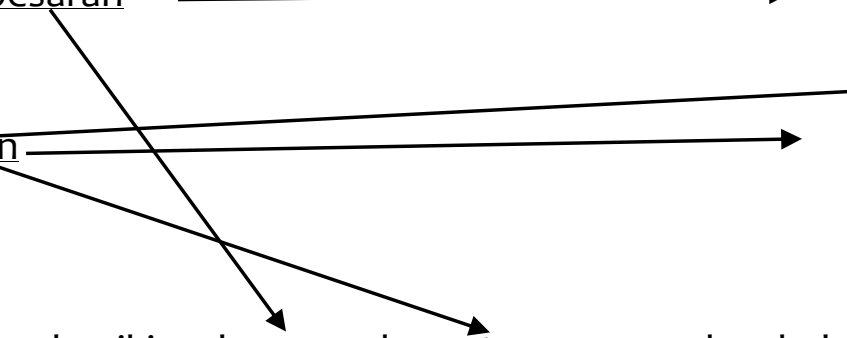

adalah segala sesuatu yang berfungsi sebagai pembanding pada suatu besaran.

7. Dengan demikian, besaran dan satuan merupakan hal yang selalu berkaitan. 
Target Language (TL): English Text

Text 1 (paragraph 1):

Theme

Rheme

Before learning about quantity and unit, do the following small activity.

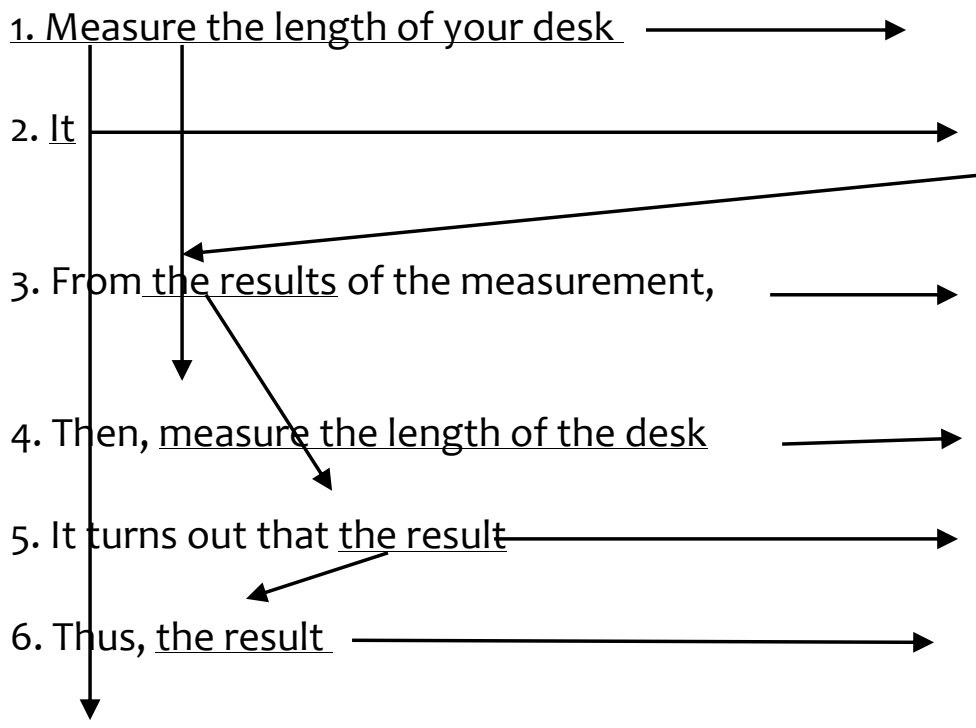

7. Measure the desk with a ballpoint.

turns out that the result is eight times of the ballpoint's length.

we can write the length of the desk $=8$ ballpoints.

using palm leaf ribs.

is three times the rib's length.

can be written as the desk length $=3$ palm leaf ribs .

using other tools and write the results. 
Text 2 (paragraph 2)

Theme

Rheme

1. From the activity, it can be concluded that to measure means an activity of comparing things.

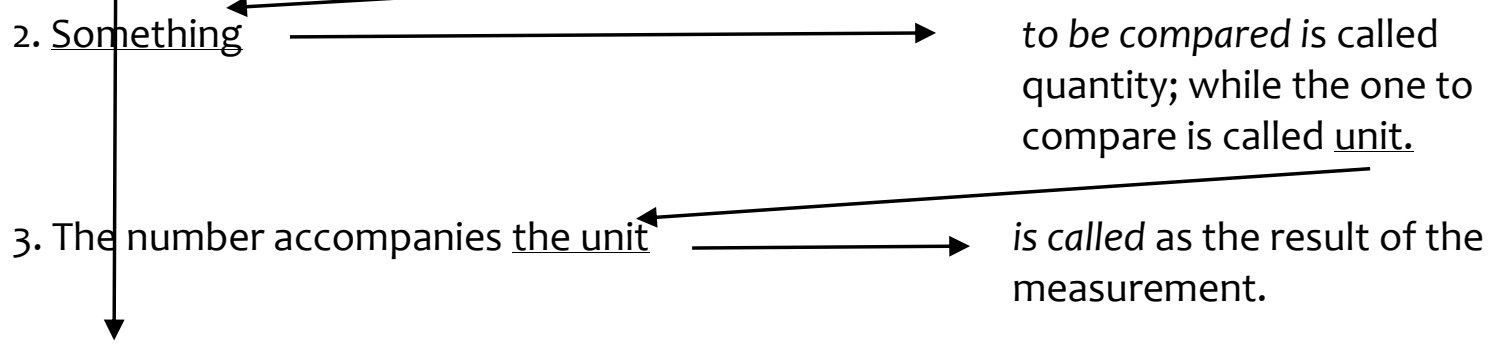

4. In the activity is you have done, $\longrightarrow$ length is the quantity and baltpoint and ribs are the units.

5. Thus, quantity is something that can be measured and has unit.

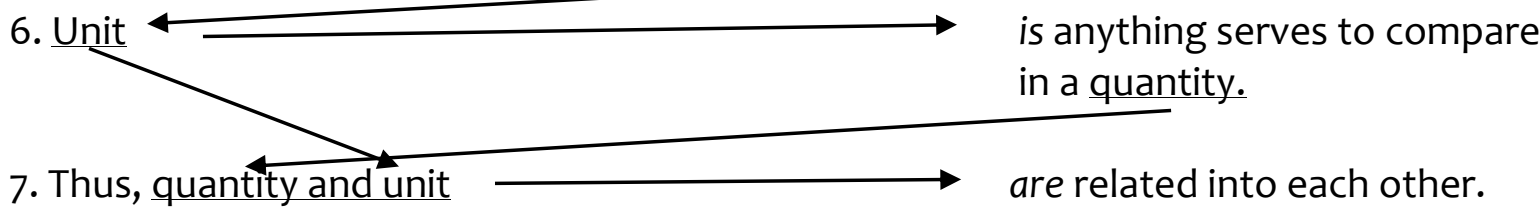

From the analyzing of the texts above, we can see that the kind of the rheme in the text 1 both in Indonesian text and language text used Progression with constant theme. It means that the same theme repeated for the next sentences. For the text 1 in paragraph 1 , the theme of the first sentence is panjang meja. Then the theme for the second until seventh sentences are also panjang meja. It is considered to the kind of the theme, such as below:

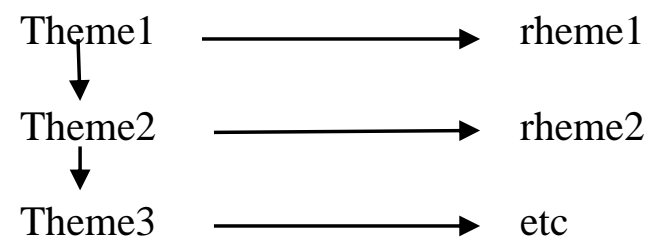


While in the second paragraph, the kind of the theme used is linear progression. It means the rheme of a sentence becomes the theme of the immediately succeeding sentence.

For the first sentence the theme is mengukur, the rheme contains element (membandingkan sesuatu) which becomes the theme of sentence 2; the rheme of sentence 2 contains element (satuan) whic becomes theme in the third sentence; but in sentence four the theme (dalam kegiatan yang kalian lakukan tersebut) comes from sentence one (dari kegiatan tersebut); while the theme of sentence five comes from the element of rheme in previous sentence (besaran). The rheme contains element (satuan) which becomes the theme in the sentence six.

It is considered to the kind of the theme, such as below:

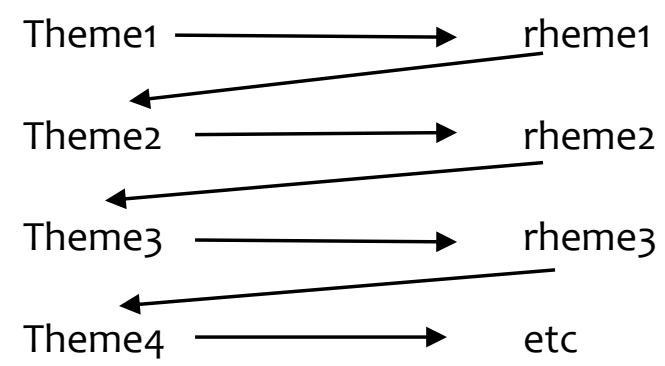

While the analyzing in the target text both in the first paragraph and second paragraph showed that they have the similarities. The first paragraph used progression with constant theme and the second paragraph used linear progression.

Let's discuss about the target text:

Paragraph 1:

It began with the theme (measure the length of your desk); the theme in the second sentence (measure) is similar with the theme in the first paragraph. In the third sentence the theme comes from the element of rheme of previous sentence (the result); while in the fourth paragraph the theme is measure the length of the desk which becomes the theme for the next sentences (it). And it also happened to the next sentence.

It is considered to the kind of the theme, such as below:

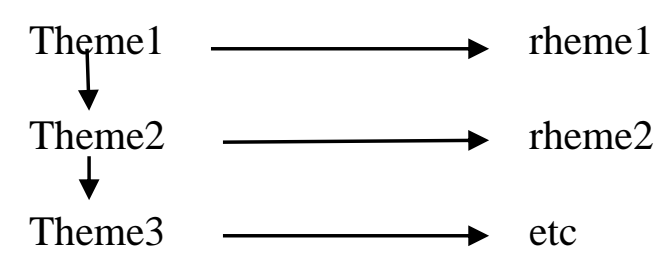


Paragraph 2:

The theme of the first sentence (to measure) contains an element of rheme (things) which becomes the theme for the second sentence (something); the element of the second sentence (unit) becomes the theme in the third sentence; while the theme of the fourth sentence (in the activity) is similar with the theme in the first sentence. Then the theme of the sentence five (quantity) comes from the element of the prior sentence. And in the last sentence (quantity and unit) becomes the theme.It is considered to the kind of the theme, such as below

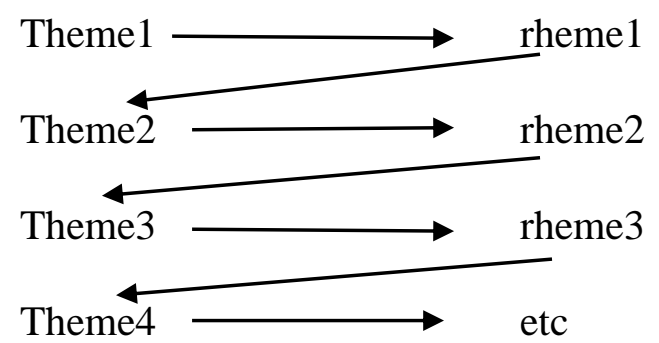

\section{Conclusion and Suggestion}

This study has done to investigate whether the theme position in both languages are similar or difference. This study also explored which kind of the theme used in the source text and target text. There are three kinds of the theme position in the sentence:

1. linear progression

2. progression with constant theme

3. progression with derived theme

In thi study we can see that the theme of the text in source text and target text are linear progression and progression with constant theme. It concluded that the position of theme and rheme in source text and target text is similar. This study has done only for two paragraph of the texts in the book, so it can not be used to make generalization about the position of theme and rheme in both languages. It still needs more researches done for other researchers related to the theme in order to make generalization. 
References

A. van Dijk,Teun. (1980). Macrostructures. Lawrence Erlbaum Associates, Publishers.

Allen, M.P. et.al. (2020). Language, Interpretation, and Translation: A clarification and reference checklist in service of Health Literacy and Cultural Respect. Publisher: National Academy of Medicine

Aryani, I.G.A.I. (2019). Grammatical Equivalence of Animal Science Terms Translation. Published by Canadian Center of Science and Education. https://doi.org/10.5539/elt.v12n6p199.

Baker, M. (1994). In other Words. London: Routledge.

Daroji and Haryati (2010). The Essentials of Physics for Grade VII of Junior High Schooland Islamic Junior High School

Dejica,D. and Mihaela C. (2013). Using Theme-Rheme analysis for improving coherence and cohesion in target-texts: a methodological approach. Procedia - Social and Behavioral Sciences.

Ethelb, H. (2019). Thematic Analysis in Translating English and Arabic Scientific Texts. Australian International Academic Centre PTY.LTD.

Hatim B. and Munday J. (2004). Translation: An advanced resource book. Routledge.

Kellou, Y. And Boucherikha,H. Translation Types Versus Translation Methods: Some Technical, Literary and Pragmatic Examples.

Laviosa, Sara.,et.al. Textual and Contextual Analysis in Empirical Translation Studies, Springer.

Leonard, D. (2011). From Narrative to Analytical: Using Theme/Rheme to Scaffold Students' Revisions Between Genres of Writing. The Catesol Journal.

McCarthy, M. (1991). Discourse Analysis for Language Teachers. Cambridge University Press. 